\title{
OPPORTUNITIES FOR FINANCING THE SUSTAINABLE DEVELOPMENT OF THE PRODUCTION OF ORGANIC GRAPES AND ORGANIC WINE THROUGH THE RATIONAL USE OF EU STRUCTURAL FUNDS AND FUNDS FROM THE NATIONAL PROGRAM FOR DEVELOPMENT OF THE WINE SECTOR
}

\author{
A. Miteva* \\ Economy of Natural Resources Department, UNWE, Sofia, Bulgaria
}

\begin{abstract}
Over the last ten years, there has been a global steady increase in the production and consumption of organic products, in particular wines produced from certified organic raw materials. The purpose of this article is to present the regulatory framework for the production of organic grapes and organic wine and the possibilities for developing their production through the use of EU structural funds and funds from the National Program for the Development of the Wine Sector
\end{abstract}

Key words: organic grapes, organic wine, structural funds, National program for the development of the wine sector

\section{INTRODUCTION}

Viticulture and winemaking are part of the agricultural economic system and they need to function in accordance with the requirements and principles of sustainable development and be compatible with other economic systems in the economy. The common organization of wine is among the areas of the Common Agricultural Policy, which is characterized by a high degree of regulation of all elements of the process of production, processing, and trade. Moreover, in the sector the agrarian policy is carried out in the conditions of interaction with the professional organization of the producers and processors of grapes - the National Vine and Wine Chamber.

In accordance with the requirements of the Common Agricultural Policy in viticulture and winemaking, the requirements for environmental protection and safety of agricultural products are increasingly observed. The implementation of the principles of organic production implies protection of biological diversity, limitation of damage to

\footnotetext{
*Correspondence to: Albena Miteva, Sofia, UNWE, Economy of Natural Resources Department, tel: 0888 869620, e-mail: albenakm@yahoo.com
}

nature as a result of agricultural activity, prevention of the use of genetically modified products, limited use of mineral fertilizers and plant protection products, etc. Evidence in this aspect according to some authors $(1,2)$ is the gradual establishment of organic farming worldwide, which implies the provision of a number of certification programs for the activities of economic entities in order to prove quality and equal participation in the competitive market competition.

Over the last ten years, there has been a steady increase in the production and consumption of organic products, in particular grapes and wines produced from certified organic raw materials. Organic viticulture gained popularity in European countries in the 80s of the twentieth century, in the 90 s the production of grapes in an organic way increased significantly, and this trend continues to this day. A number of studies $(3,4)$ show that production of wines from organic grape raw materials is increasing at the fastest pace in the European Union over the last five years.

According to D. Dimitrova and V. Dimitrov (3, $5,6)$ organic farming can be considered as a system for production of quality and environmentally friendly products, which does 
not allow the use of chemical fertilizers, synthetic agrochemicals, genetically modified organisms and other chemicals. This ensures the protection of the environment, preservation of biological diversity in the ecosystem and meeting the requirements of consumers (7-9).

The differences between conventional and organic viticulture are mainly due to the applied technological measures regarding the fertilization system, soil surface maintenance and plant protection. In the organic production of grapes to maintain the soil surface in the vineyards, grassing, mulching and mechanical tillage are mainly practiced. The fight against diseases and pests is carried out through the complex application of the following measures: selection of suitable varieties and places for the vineyards; appropriate pruning and care of the vines and controlled use of permitted fungicides, such as sulfur and Bordeaux mixture $(7,9)$. The production of wine according to the principles of organic farming is carried out on the basis of requirements for the method of grape harvesting, the facilities for processing the grapes, the vessels for vinification and storage of wine, as well as the application of a minimum number of physical methods for its processing $(10,11)$.

The first attempts to grow vines according to the requirements of organic farming in Europe were made in the 50 s of the twentieth century in Switzerland and Germany and were accompanied by a significant reduction in yields. As a result of research carried out in the 1980s to establish efficient methods and means of preserving grape production in accordance with the principles of organic production, the number of organic vine-growing farms increased significantly, initially in Switzerland and then in many other European countries (12).

The concept of organic wine is not new, as the products produced until the adoption of EU requirements have been subject to much stricter standards.

An additional stimulus for expanding the market niche of organic wine is the increased demands of consumers on food safety and security, the strong emphasis on their role in protecting human health, the growing concern for environmental protection and the introduction of sparing plant protection products and practices. The changed consumer habits stimulate the production and trade of organic wine, as a large part of the consumers believe that it has a better taste, higher quality, better impact on the environment, that it is a guarantor of their health and safety. (13)

Based on the rules for the production and trade of organic products defined by IFOAM, a number of European, national regulations and long-standing good practices define the requirements and standards for all stages of the process related to the cultivation of organic grapes and bio-wine production. Leaders in the development of these standards and rules are producer groups /Germany, France, Austria/, non-governmental organizations engaged in the promotion of organic farming and related to certification bodies /Austria, Germany, Switzerland, Italy, Greece/, certification organizations /Spain/ and representatives of branch organizations engaged in the production of bio-wine /Spain, Switzerland/. In general, bio-wines are defined as wines produced from grape raw materials, which are obtained by completely modified methods of vine treatment, which excludes the use of inorganic chemicals, pesticides, fungicides, and herbicides.

In fact, organic wine is not a novelty on the market - different private and national standards for organic and biodynamic agriculture (Demeter, Naturland, BioSuise, FNIVAB) with criteria much stricter than those of the EU, allow such labeling of wine. They are created on the basis of decades of experience in this field of countries with traditions in organic farming and wine production.

\section{NORMATIVE REGULATION OF THE PRODUCTION OF ORGANIC GRAPES AND WINE}

In the European Union in 1991 the European Council of Agricultural Ministers adopted Regulation № 2092/91 on organic production of agricultural products and their designation, thus completing the process of official recognition of organic farming in the $15 \mathrm{EU}$ Member States.

Based on this legislation in our country, a number of regulations were adopted, as well as the Law on the Implementation of the Common Organizations of the Markets of Agricultural Products of the European Union, 
which entered into force on January 1, 2007. The Minister of Agriculture and Forestry pursued a quality policy that covers the rules for the protection of geographical indications, for the recognition of traditional specific character and for the organic production of agricultural products and foodstuffs.

Almost two decades after the creation of European legislation on organic farming, wine is part of it. Previously, wines could only be labeled as "produced from organic grapes" to indicate that the raw material is organically certified, but due to the lack of requirements for the vinification process, the wine could not be labeled as "organic". After long discussions, negotiations, and results of the ORWINE project, the EU Member States reached an agreement with Regulation 203/2012 of 8 March 2012. It allows after 31.07.2012, a wine produced by an oenological process in accordance with the Regulation to be designated as "Organic wine", using the EU organic label. The document provides for the possibility that stored wines, for which compliance with the new requirements can be documented, also to be designated as "organic wine".

Currently, the rules for organic production of grapes and wine are regulated by Ordinance №1 of 7 February 2013 on the application of the rules of organic production of plants, animals and aquaculture, plant products, animal products, aquaculture products, and foodstuffs, their labeling and control of production and labeling. It lays down the conditions and procedure for applying the rules for the production of organic grapes and wine in accordance with the requirements of European legislation and in particular of Commission Regulation № 203/2012 (EU) on amending Regulation (EC) № 889/2008 laying down detailed rules for the application of Council Regulation (EC) № 834/2007 as regards detailed rules concerning organic wine. The positive point for the producers, in this case, is that new and uniform rules are introduced for the countries of the European Community, defining the permitted technological practices in the production of organic wine from organic grapes, which creates the guarantees required by consumers for product quality and safety. For the implementation of this legislation in the country there are already established and functioning administrative structures, as well as bodies for control and certification of the process of organic production and the obtained finished products.

It is emphasized that the guiding principles for the processing of vegetable raw materials also apply to wine production. "Organically produced products are required to be produced using processing methods that ensure that the organic integrity, and basic qualities of the product are maintained throughout all stages of the production chain."

Organic wine must be produced from organically certified grapes. This happens after a three-year process of transition of the respective production plantations, in which the methods of organic farming are applied. The main concern is the health and fertility of the soil, preservation and maintenance of biodiversity, with special attention to the species - natural enemies of pests and diseases of the vine. The use of synthetic pesticides and fertilizers, as well as GMO organisms, is prohibited. Emphasis is placed on prevention, if necessary, copper-containing, sulfurcontaining preparations and other permitted products based on plant extracts and strains of microorganisms with a proven insecticidal effect are used. The result is a healthy, pesticide-free production that contains and transmits the specific characteristics of terroir and wine. It is characteristic of organic wines that they develop a unique taste, depending on the place of cultivation, climate and soil. (13) The processing of the grapes must be carried out with the minimum necessary practices and additives in order to preserve the biological nature of the wine. Regulation 203/2012 defines the permitted, restricted, and prohibited oenological practices in wine production. As no alternatives have been found for some of the oenological practices in winemaking to date (eg such as heat treatment and the use of ion exchange resin to remove grape must or reverse osmosis), they are partially acceptable. The use of thermal treatment exceeding $70^{\circ} \mathrm{C}$ is also limited, as is the use of filters with pores smaller than 0.2 micrometers (these are the so-called ultras and nano-filtrations). This definitely reflects on the clarity of the organic wine, but in no way affects its quality, on the contrary, this dense and saturated color that remains on the walls of the empty glass after we have already drunk, can only be observed in unfiltered wines. 
Regarding the additives used in processing, half of them are allowed in conventional wine production and in organic wine production. All additives that are of natural origin are allowed (plant, mineral, microorganisms and yeast that are free of GMOs).

$50 \mathrm{mg}$. per liter - lower than conventionally produced wines.

There are differences in the definition of organic wine between the EU, the US and Canada. The United States defines that organic wines are those produced from organic grapes without the addition of sulfites, while Canada and the EU allow the addition of sulfites in certain quantities. In the United States, strict rules apply to control each stage of organic wine production, including harvesting, the type of yeast that can be used during fermentation, and storage conditions. Additional difficulties are created by the differences in the legal framework and the rules for certification between the individual countries. In the EU, the label of a bio-wine mentions not only the code or name of the certifying authority of the country but also those of the EU inspection body.

The new regulation has clear boundaries between organic and conventional wine, which gives us the positive attitude that organic wine comes from clean land produced according to the principles of organic farming. It can be concluded that the current legislation is a prerequisite for a clear distinction between organic wines and wines produced by conventional methods.

\section{OPPORTUNITIES FOR DEVELOPMENT OF THE ORGANIC PRODUCTION OF THE WINE SECTOR THROUGH RATIONAL USE OF THE EU STRUCTURAL FUNDS}

The development of the wine sector and the vineyards in Bulgaria is carried out with financial resources allocated under the measures of the state support programs for both the wine sector and the agricultural sector as a whole. The EU Structural Funds are the necessary financial resource, and their rational use affects the competitiveness of the wine industry.

The implementation of some of the guidelines for the development of the wine sector is influenced by the developed 19 measures of the Rural Development Program for the period
2014-2020. 6 main priorities have been formulated to achieve the objectives. With regard to sulphites, the quantities of sulfur dioxide (SO2) required depend on the different categories of wine as well as on certain characteristics of the wine and in particular its sugar content, which should be taken into account when setting maximum levels of sulfur dioxide for organic wines. The maximum permitted limits are about program, which is aimed at:

- Stimulating knowledge transfer and innovation in agriculture and forestry and rural areas

- Increasing the viability of agricultural holdings and the competitiveness of all types of agricultural activity

- Promoting the organization of the food chain, including the processing and marketing of agricultural products

- Restoration, protection and strengthening of ecosystems related to agriculture and forestry

- Promoting resource efficiency and supporting the transition to sustainable climate change

- Promoting social inclusion, poverty reduction, and economic development in rural areas.

The development of skills and knowledge transfer for new technologies, renewable energy sources, organic farming products, etc. and improvement of environmental management skills can be achieved through the use of Measure M01 of the Rural Development Program - Transfer of knowledge and information activities. Under this measure, registered wine and dessert wine growers have the right to participate in long-term and shortterm training courses, as well as to participate in various information activities such as: seminars, information sessions, workshops and demonstration projects. This measure will help farmers in the wine sector to improve their professional skills in the field of agriculture. At the same time, farmers will be able successfully to adapt to the introduction of a number of Community standards and requirements related to their activities. Vocational training will increase the opportunities for obtaining additional income and for acquiring new knowledge by the employees in the sector. The operational objective of this measure is to ensure an adequate level of technical and economic knowledge and skills in the field of management and business, new technologies, product quality and safety, sustainable 
management of natural resources, including cross-compliance requirements, renewable energy sources and organic production.

Agricultural holdings in the wine sector may also benefit from measure M06 "Development of the economy and economic activity", submeasure 6.1. "Start-up aid for young farmers". The creation of farms from young farmers is a guarantee for the future of the wine sector. They are holders of new skills and professional qualifications in the agricultural sector. This measure will help to redirect funds to rural development in order to finance various measures, incl. environmental protection and support for young wine producers. Funding for agro-environmental schemes in rural development programs can also be increased. Under this measure, young people between the ages of 18 and 40 who are now starting farming can receive funding to support the creation and restructuring of their farm, including the cultivation of vineyards, according to a business plan submitted and approved by the Paying Agency. The use of this measure by young farmers in the wine sector will support the process of establishing their farms and modernizing them in accordance with the requirements of occupational safety, environmental protection and more.

The modernization of agricultural holdings in terms of technology, management and organizational practices and the reduction of production costs and environmental protection costs can be done through the use of funds under measure M04 "Investments in tangible assets". At present, some of the vineyards in Bulgaria have a relatively low level of productivity and outdated technical equipment. In order to improve the activity of the vineyards in the country, significant investments in tangible and intangible assets are needed in order to meet the Community standards. Under this measure, registered farmers growing wine and dessert vineyards can receive funds to modernize and improve their competitiveness. They will be supported for the purchase of machinery, equipment and facilities for the reconstruction and construction of production buildings and more investments.

Through this measure, vineyards could improve their overall performance and competitiveness by modernizing production conditions and introducing new processes and technologies aimed at producing quality agricultural products. At the same time, the use of this measure will contribute to compliance with Community standards and to the improvement of conditions on agricultural holdings, in particular as regards safety and safety at work.

Rationalization of the structure of vineyards can be done through measure M09 "Establishment of producer groups and organizations". The unfavorable structure of agricultural holdings and the insufficient unification of agricultural producers make it difficult to supply the market with the necessary quality and quantity of agricultural products. At the same time, processors are short of raw materials and products and supplies from a large number of small suppliers are inefficient. This can be overcome by setting up producer organizations or producer groups. It will improve cooperation between farmers in order to increase the competitiveness of both agriculture and the food processing industry. This measure will support organizations or groups of farmers growing vineyards. Financial assistance will be paid in the form of an annual payment granted for five consecutive years from the date of recognition of the organization.

In addition to the above measures, all winegrowers whose areas fall into a disadvantaged area will receive compensatory payments for working under less favorable production conditions under measure M13 "Payments for areas facing natural or other specific restrictions'. The establishment of producer organizations in the agricultural sector is expected to help increase the production and supply of high quality products that meet European standards and market requirements. Joint marketing of agricultural products will facilitate market access for small and medium-sized farms. The measure supports the establishment of producer organizations in the agricultural sector.

Aid under this measure shall be granted to facilitate the establishment and administrative operation of producer organizations for the purpose of adapting members' production and production to market requirements, collecting the products produced by members and placing them on the market, including preparation for sale, centralization of sales and delivery to 
wholesale buyers, increasing the added value of total production and better pricing, creating common rules and information base on products with a specific focus on produced and existing stocks. Closely related to it is measure M 16 "Cooperation", sub-measure 16.1. "Support for the formation and functioning of operational groups within the EMI for agricultural productivity and sustainability", sub-measure 16.2 "Support for pilot projects and for the development of new products, practices, processes and technologies". The realization of the production in the sector is done mainly through direct sales and therefore the stimulation of the vertical and horizontal integration of producers, processors and traders in order to introduce the marketing approach and in order to build sustainable local markets and short supply chains can be done measure 16.4 of the RDP 2014-2020.

The market for organic products in the EU and worldwide is developing dynamically, growing steadily despite the crisis. The CAP for the 2014-2020 programming period provides for $30 \%$ of direct payments to be set aside for socalled "green direct payments". Organic producers receive unconditional "green direct payments" for the areas in the control system. The regulation for supporting rural development for the period 2014-2020 applies a new measure: "Organic farming". This is a great recognition of the growing importance of organic farming in the EU. The fact is that the demand for organic products is increasing every year. Europe is the second largest producer in the world, and in Bulgaria the trend of development of organic production is also positive. Most of the Bulgarian organic foods and products are intended for foreign markets.

The annual amount of payments for the transition to organic farming (transition period) for vineyards is 736 EUR / ha, and the annual amount of payments for organic farming for vineyards is $557 \mathrm{EUR} / \mathrm{ha}$. Two sub-measures are implemented under this measure:

Sub-measure 11.1 Payments for the transition to organic farming per hectare of UAA;

Sub-measure 11.2 Payments for the maintenance of organic farming per hectare of UAA.

The measure has a positive effect and contributes to the sustainable development of rural areas, contributing to the protection of the environment and mitigation of the effects of climate change and the support of small and medium-sized farms, most of which are family-run. It assists farmers in the wine sector in introducing environmentally friendly farming methods and provides benefits to society as a whole. Farmers wishing to grow wine and dessert vineyards in an organic way, receive payments under it. This measure helps vine-growers to increase the understanding and knowledge about the impact (positive and negative) of agricultural practices on the environment, especially with regard to soil and water management and biodiversity conservation, which stimulates the use of environmental planning in farm management practices. It also contributes to the improvement of soil and water resources, including in areas affected by severe erosion or threatened by nutrient contamination or other forms of pollution from agricultural sources.

\section{RECOMMENDATIONS FOR RATIONAL USE OF THE FUNDS SET IN THE NATIONAL PROGRAM FOR DEVELOPMENT OF THE VINE AND WINE SECTOR FOR GREENING OF WINE FARMS}

There is continuity between the Program for support of the wine sector and the OP "Rural Development Program", which helps more fully to absorb the funds and to increase the competitiveness of viticulture and winemaking. The National Program for Support of the Wine and Wine Sector of Bulgaria, which is implemented for the period 2014-2018, is supported by the European Commission. The changes from 2016 support the implementation of two measures, "Restructuring and conversion of vineyards" and "Promotions in third countries", which are also applied under the previous national program.

The measure "Restructuring and conversion of vineyards" is of major importance for the program. The objectives to be achieved with the implementation of this measure are to increase the competitiveness of grape growers, increase the market orientation of vineyards, by improving management technologies and planting new varieties preferred by the market, increasing the production share of quality and table wines, increase in the areas with the vineyards for production of quality wines, etc. The activities that are supported under the measure "Restructuring and conversion" are 
change of the varietal composition of the plantations, restructuring of the vineyards and improvement of the methods and technologies for the management of the vineyard. For the implementation of each of these activities are provided operations that are supported, as the maximum amount of financial assistance is up to $75 \%$ of the value of the actual costs of implementation of each specific activity.

The European Community has allowed Bulgaria to have $1,200,000$ decares of vineyards intended for the production of wine and other grape products, and this limit must be respected.

In Bulgaria, the rights of planting and replanting of vineyards are regulated by the Ordinance on the terms and conditions of planting and replanting and management of the National Reserve. The European Commission has granted Bulgaria rights for new planting in the amount of $1.5 \%$ of the total vineyard area of the country, which is equal to 2,295 ha and they are part of the National Reserve. This high amount of new planting rights stimulates the development of viticulture. In addition, this ordinance regulates the rights of replanting, which farmers can acquire for a period of 5 to 8 years in order not to be deprived of income until the beginning of the fruiting of new plantations. This stimulates the process of renewal of the varietal structure with such grape varieties that are in demand on the market but helps to reduce the planted traditional local varieties. The relatively easy and cheap access to planting rights in Bulgaria hinders the development of a real market of rights between farms, which reduces the effectiveness of this measure to control the production potential in viticulture. Some control is achieved over the planted areas, but not over the yields.

The measure "Promotion of third country markets" refers to wines with a protected designation of origin or geographical indication, or wines with a wine grape designation. The aim is to increase the knowledge and consumer interest in Bulgarian quality, regional and table wines with designation for variety and vintage, building a positive image of Bulgarian quality wines and imposing Bulgarian designations of origin and brands as known and sought after by consumers in third countries, promoting trade in Bulgarian quality and regional wines on third country markets by engaging the efforts and attention of key market players (retailers, hotel chains, tour the attention of key market players (retailers, hotel chains, tourist chains and etc.), raising consumer culture by cultivating a taste for the consumption of quality wines, thus increasing the average price of domestic exports. Promotional programs to improve marketing and awareness of thirdcountry consumers about the variety, quality, and production conditions of wines in Bulgaria are a good way to reduce the negative effects of the pressure exerted by the growing number of foreign producers.

The procedure for support under the measures includes, in general, the submission of an application, with the relevant annexes, evaluation and conclusion of a contract with the approved applicants. Competent institutions for the administration of the measures under the program are EAVW and SFA.

An important factor for the development of organic wine production is the funds provided under the measure "Investments" of the National Program for Support of the Wine Sector of Bulgaria for the wine years 20142018 , one of the goals of which is to stimulate the growth of production of organic wine up to $2 \%$ of the total amount of wine produced in the country. The provision of financial support also aims to promote the use of environmental practices based on the application of fewer pesticides, the protection of soil from pollution, the maintenance of biodiversity, and the landscape.

\section{CONCLUSION}

The development of the production of organic grapes and organic wine in the wine sector in the future will be carried out on the basis of its established structure, as well as the created prerequisites and conditions for the manifestation of its competitive advantages. The main prerequisites for this are the good natural and climatic conditions of the country for the development of the available viticultural potential and the built capacity for production of quality wines. A reasonable alternative for development is the accelerated increase of the relative share of quality wines by modernizing the technologies and improving the varietal structure of the vineyards. In some wine-growing regions for the development of the wine sector will have 
an impact and domestic tourism and related tourist products offered on the basis of established roads of wine.

For Bulgarian wine producers, the main factor for maintaining and maintaining market shares is improving the quality of the wine offered. The main problem facing the country is the restructuring and, at the present stage, the renewal of the vineyards. The restructuring of the wine sector is a key element in achieving strategic goals. Only by building a modern structure of the sector can the influence on the market be increased and the efficient use of resources is ensured.

\section{REFERENCES}

1. 1.Atanasov A, Shishiniova M, Rakleova G et al., Problemi I perspektivi pred biologichnoto zemedelie, Nacionalna konferencia "Biologichno rastenievadstvo, jivotnovadstvo I hrani”, SSA, S., pp.7, 2014

2. Iovchevska Pl. Biologichnoto proizvodstvo: Paradigma na semeinoto zemedelie, Nacionalna konferencia "Biologichno rastenievadstvo, jivotnovadstvo I hrani", SSA, S., pp.15, 2014

3. Dimitrov, Dimitrova, Regionalni aspekti na lozarstvoto I vinoproizvodstvoto $\mathrm{v}$ Bulgaria, Journal of Mountain Agriculture on the Balkans, 20 /3/, pp. 162-186, 2017

4. Kirechev D., Prostranstveno koncentrirane I integrirane v lozaro-vinarskia sector, sp. Izvestia, IU Varna, br. 1, 2012

5. Dimitrova D, Simeonov I., Dimitrov V., Perpektivi pered razvitiem biologicheskova proizvodstva vinograda I vina $\mathrm{v}$ Bolgarii, Mejdunarodna konferencia, Novocherkask, pp. 48-55, 2014

6. Dimitrov V., Dimitrova D., Vinenite patishta v Bulgaria: problem pri sazdavane
I regulirane, sp. Upravlenie I obrazovanie, tom XII/2/, pp. 72-79, 2016

7. Braikov E, Ivanova D., Biologichno proizvodstvo na grozde, Plovdiv, pp.74, 2006

8. Boudzine-Chameeva, T., Barriers and driving forces in organic winemaking in Europe: case studies in France and Italy, $6^{\text {th }}$ AWBR International Conference, 9-10 june, Bordeaux Management School, France, 8 pp. http://academyofwinebusiness.com/wpcontent/uploads/2011/09/5-AWBR2011Bouzdine-Chameeva-Krzywoszynska.pdf, 2011

9. Vasileva E., Ivanova D., Biologichnite vina, Hranitelna industria\&targovia vol. 1, pp. 22-23, 2005

10.Ioncheva T., Todorova M., Vachevska D., Technologichni aspekti pri biologichnoto proizvodstvo na grozde I vino $\mathrm{v}$ raiona na grad Pleven, Sbornik s dokladi "Kachestvo na stokite - problem I perspektivi', IU Varna, pp 280-287, 2006

11.Trifonova P., Todorova M., Ioncheva T., Atanasov P., Parvi rezultati ot prouchvaneto na vazmojnostite za proizvodstvo na ekologichno chisto grozde I vino, sb. 100 godini Institut po lozarstvo I vinarstvo, SPS PRINT, Sofia, pp. 344-349, 2002

12.Willer, H., Organic viticulture in Europe and the European Union, In: EU rules for organic wine production. Background, evaluation and further sector development, IFOAM EU Group, Brussels, pp.32-34, 2013

13.Ioncheva T., Haigarov V., Biologichnoto vinoproizvodstvo - rezultati $\mathrm{v}$ Institut po lozarstvo I vinarstvo, Pleven, Hranitelna vkusova promishlenost, vol. 10, pp.49-52, 2012 